\title{
EFFECTS OF TWO REARING SYSTEMS ON THE DEVELOPMENT OF DIGESTIVE ORGANS AND SLAUGHTER PERFORMANCE OF LUSHI GREEN LAYER BIRDS
}

\author{
N. LI, J. L. WANG, T. S. XU*1, X. Q. LEI ${ }^{1}$, Q. J. WU, N. LIU ${ }^{1}$ \\ F. Y. WEN ${ }^{1}$, L. Z. GAO ${ }^{2}$ AND Z. Q. XIAO ${ }^{2}$ \\ College of Animal Science and Technology \\ Henan University of Science and Technology \\ Luoyang, Henan- 471 023, China
}

\begin{abstract}
This study evaluated the effects of two management systems (battery cage and semi-intensive) on the digestive organ development and slaughter performance of Lushi green layer birds. Sixty layer chickens, Lushi green, seven weeks old were used. Thirty chickens were placed in each of the two systems. Ten (half male and half female) chickens from each management system were selected randomly for slaughter and relevant indexes were measured. Results showed that the liver, gizzard, pancreas and gizzard organ indexes of the roosters reared under the semi-intensive system were higher than those of the cage reared roosters $(P<0.05)$. The digestive organ index of the hens reared under the semi-intensive system was also higher than that of the cage reared hens $(\mathbf{P}<\mathbf{0 . 0 5})$. The lengths of the jejunum, ileum, and ceca and the jejunum relatively small intestine index of the chickens reared under the semi-intensive system were higher than those of the cage reared chickens $(\mathbf{P}<\mathbf{0 . 0 5})$. The thigh muscle and abdominal fat yields of male and female chickens reared under the semi-intensive system were lower compared with those of the cage-reared ones $(\mathbf{P}<\mathbf{0 . 0 5})$. These results indicated that rearing method influences the slaughter performance and digestive organ development of Lushi chickens. The digestion and absorption abilities of chickens reared under the semi-intensive system were generally better than those of cage-reared ones.
\end{abstract}

Key words: Digestive organ, Lushi green layer birds, Rearing system, Slaughter performance

Lushi green layer birds are excellent indigenous meat and egg-type local chicken breeds that display green-shell eggs and red- black feather (Xu et al., 2009). The particular birds are rich in nutritive and medicinal values, and formed through long-

*Corresponding Author

${ }^{1}$ The Key Laboratory of High-quality Poultry Germplasm Resources and Genetic Breeding of Luoyang, Luoyang, Henan- 471023, China

${ }^{2}$ Lushi County Animal Husbandry Bureau, Lushi, Henan- 472200, China 
term natural selection in the Lushi mountainous region in Henan Province, China (Zhou et al., 2016). Lushi green layer birds exhibit a slow growth rate, high egg production, delicious meat, and a strong tolerance for and adaptability to coarse feed (Ma et al., 2009). The egg of Lushi green layer birds is rich in selenium, zinc and iodine; it also features low-cholesterol content and serves several healthcare functions, such as prevention of cardiovascular disease (Huang et al., 2017). Such egg is considerably popular among consumers, and its market price is two or three times higher than that of commercial layer birds.

Lack of housing has been a major problem in Lushi green layer bird production in the region. Poor housing of chickens generates heat stress effects, such as low production, suppressed reproduction, reduced feed intake and reduced egg production (Njoya and Picard, 1994). Hameed et al. (2012) who found that housing conditions of poultry birds play very important role and poultry parent stock should be provided the conditions that ensure optimum performance of the birds. Therefore, improving the housing system of chickens could help minimize the effects of heat stress and establish breed standards. Poultry stock improvement could also increase the yield of laying hens.

Birds under the semi-intensive rearing system are housed at night but allowed to roam freely during daytime in a restricted area (Barbosafilho et al., 2005). Some consumers are also interested in birds raised with access to the outdoors. Many consumers buy these products because they believe that outdoor production systems enhance the flavor of chicken compared with conventional confinement systems (Fanatico et al., 2005). Semi-intensive rearing system without any confinement on birds could decrease stress conditions and allow selection of strains that may increase comfort and bird welfare. Chickens under the semi-intensive system are supplemented with either commercially formulated or homemade feed, clean water is provided ad libitum, and disease control measures are executed. This system is also an updated alternative system for raising the living standards of rural households by supplying additional income and supplement protein intake in rural and tribe folks (Niranjan $e t$ $a l ., 2008)$. Chickens reared under the semiintensive system are at high risk of being infected with diseases and ectoparasites due to contamination with soil dust and vegetation when they roam around during daytime (Muchadeyi et al., 2004; Rodenburg et al., 2005). An infestation with red mites can lead to reduce weight gain, anemia and increase mortality (Kilpinen $e t$ al., 2005).

The battery cage system allows large capacity, convenient management and high coop utilization rate. This system also favors disease control and prevention, short growth cycle and product security. However, layer chickens in conventional cages are subjected to restricted movement and cannot 
fulfill most of their natural behaviors (Vits et al., 2005). Caged hens are prevented from dust bathing and roosting because they are deprived of litter and perches. Movement restriction induces bone disease, particularly in legs and wings (Baxter, 1994). Conventionally confined systems cause animal stress (Jones and Millis, 1999; Marin et al., 2001), which results in poor performance (Mendl, 1999). Dereuk et al. (2008) reported that the conventional cage housing system for laying hens has been abolished in the European Union (EU) since 1st January 2012 in accordance with the EU directive (1999/74/EC); the furnished cage and non cage system, which allows bird movement, has been used as an alternative.

Various studies have investigated the effect of different feeding methods on the laying performance and economic benefit of layer chickens. However, the effects of different rearing methods on the slaughter performance and digestive organ development of Lushi green layer birds remain unclear to date. Therefore, this study explored the effect of different rearing patterns on the slaughter performance and digestive organ development of Lushi green layer birds.

\section{MATERIALS AND METHODS}

Birds and diets: The study was carried out at the Bokang Lushi Chicken Development Co. Ltd. of Lushi County, Henan Province, Henan University of Science and Technology from July 2014 to December 2014. Lushi is situated at latitude of $33^{\circ}$
$332 \sim 34^{\circ} 232 \mathrm{~N}$ and longitude of $110^{\circ} 352$ $\sim 111^{\circ} 222 \mathrm{E}$ in the west of Henan Province. The study area is characterized by a temperature range of $12 \sim 13.4^{\circ} \mathrm{C}$, a relative humidity of about $71.6 \%$ and an annual mean rainfall of about $692.9 \mathrm{~mm}$.

In this study, sixty 7-week-old Lushi green layer birds with medium-heavy egg type were obtained from Bokang Lushi Chicken Development Co. Ltd. of Lushi County. In the experiment, ten 18-week-old Lushi chickens (half male and half female) were randomly selected from the semi-intensive system and the battery cage system for slaughter, and relevant indexes were measured.

The sixty birds were equally divided into the two treatment groups (battery cage and semi-intensive systems). Birds in the two management systems were reared for twelve weeks (7-18 weeks). The experimental design and procedures were approved by the Institutional Animal Care and Use Committee of Henan University of Science and Technology.

Battery cage system: Two layer chickens were reared in a cage with the following dimension: $0.6 \mathrm{~m}$ length, $0.4 \mathrm{~m}$ width, 0.42 $\mathrm{m}$ front height and $0.36 \mathrm{~m}$ rear height. The light exposure was $10 \mathrm{~h}$ light/day for the whole duration of the study. Feed and water troughs were placed in the cage.

Semi-intensive system: In this system, a fence structure with an area of $121 \mathrm{~m}^{2}(11 \mathrm{~m}$ length $\times 11 \mathrm{~m}$ width) was constructed in such a way that the birds can roam around during 
Table 1. Ingredient and nutrient composition of the experimental $\operatorname{diets}^{1}$

\begin{tabular}{lc}
\hline Diet composition & Amount \\
\hline Corn (\%) & 65 \\
Soybean meal (\%) & 20 \\
Premix $\left.{ }^{1} \%\right)$ & 5 \\
Bran (\%) & 10 \\
Nutrition level & \\
Metabolizable energy (MJ/Kg) & 11.46 \\
Protein (\%) & 16.07 \\
Methionine (\%) & 0.57 \\
Lysine (\%) & 0.99 \\
Calcium (\%) & 0.89 \\
Available phosphorus (\%) & 0.62 \\
\hline
\end{tabular}

${ }^{1}$ Each premix was purchased from the Henan Animal Husbandry Biological Technology Co. Supplied the following per kilogram of total diet: vitamin A (140000 IU), vitamin E (200 IU), vitamin $\mathrm{K}_{3}(25 \mathrm{mg}$ ), vitamin $\mathrm{B}_{1}(20 \mathrm{mg})$, vitamin $\mathrm{B}_{2}(80 \mathrm{mg})$, vitamin $\mathrm{D}_{3}$ (30000 IU), Cu (80 mg), Fe (600 mg), Zn (800 mg) and Mn (1000 $\mathrm{mg})$

daytime to scavenge. The stocking density in the fence was $4 \mathrm{~m}^{2}$ per bird (Thiele and Pottguter, 2008). In the house, this density was 10 birds per $\mathrm{m}^{2}$ as in the deep litter system.

Chicks were fed the same diet (Table 1). Feed in the morning and evening, clean drinking water was provided ad libitum daily, and all diets were formulated to contain adequate nutrient levels as defined by the NRC (1994).

Sample collection and analytical determination: After fasting for $12 \mathrm{~h}$ before slaughter, ten 18-week-old Lushi green layer birds were randomly selected from each treatment group. The birds were weighed individually and killed by manual exsanguinations. The samples, including abdominal fat, breast and thigh muscles, glandular stomach, gizzard, pancreas, liver and intestinal segment (duodenum, jejunum, ileum and ceca), were removed by trained personnel and weighed. The breast muscle, thigh muscle and abdominal fat were calculated as the percentage of eviscerated carcass weight. The relative organ weights (weight of organ $/ 1 \mathrm{Kg}$ live body weights) were calculated. The duodenum, jejunum, ileum and ceca were emptied by gentle 
pressure and the length and weight were recorded. The relative index of the small intestine was calculated.

Statistical analysis: All data were analyzed by SPSS 20.0 (SPSS Inc., Chicago, IL, USA) software for independent sample $t$ test and correlation analysis. Results were expressed as means \pm standard deviation (SD). Significant difference was considered at $\mathrm{P}<0.05$.

\section{RESULTS}

Digestive organs: The effects of two rearing systems on the length, weight and relative length of the intestinal segments are presented in Table 2 . The length and weight of the intestine in the roosters reared under the semi-intensive system were higher than those of the cage reared roosters $(\mathrm{P}<0.05)$. The lengths of the jejunum, ileum and ceca in the hens reared under the semi-intensive system were higher than those of the cage reared ones $(\mathrm{P}<0.05)$. No significant differences $(\mathrm{P}>0.05)$ in intestinal weight values were found between the two systems. The length and relative small intestine length indexes of the jejunum in the roosters reared under the semi-intensive system were higher than those of the cage reared roosters $(\mathrm{P}<0.05)$, but their length and relative small intestine length indexes of the ileum were less than those of the cage reared roosters $(\mathrm{P}<0.05)$. The total length of the small intestine in the chickens reared under the semi-intensive system was higher than that of the cage reared ones $(\mathrm{P}<0.05)$.

Table 3 shows the effects of two rearing systems on the organ index of Lushi green birds. The liver, gizzard, pancreas, and relative body weight indexes of the gizzard in the roosters reared under the semiintensive system were higher than those of the cage reared roosters $(\mathrm{P}<0.05)$, but no significant difference existed on other indicators $(\mathrm{P}>0.05)$. The digestive organ index in the hens reared under the semiintensive system was higher than that in the cage reared hens $(\mathrm{P}<0.05)$, whereas the digestive organ weights of the hens reared under the semi-intensive system indicated a slight increase $(\mathrm{P}>0.05)$.

Slaughter performance: The effects of two rearing systems on carcass traits are presented in Table 4. The weights of the gizzard, liver and feet of the roosters reared under the semi-intensive system were higher than those of the cage reared roosters $(\mathrm{P}<0.05)$. The abdominal fat weight of the roosters reared under the semi-intensive system was less than that of the cage reared ones $(\mathrm{P}<0.05)$. The weights of the carcass, breast muscle, thigh muscle and abdominal fat of the semi-intensive hens were less than those of the cage reared hens $(\mathrm{P}<0.05)$. In addition to gizzard and liver, other indicators were less than those of the cage reared hens, but no significant differences were observed $(\mathrm{P}>0.05)$.

The thigh muscle and abdominal fat yields of the roosters reared under the semiintensive system were lower than those of the cage-reared ones $(\mathrm{P}<0.05)$. Additionally, the other indexes of the roosters under the two systems increased $(\mathrm{P}>0.05)$. The abdominal fat and thigh 
Table 2. Effects of two rearing systems on the length, weight and relative length of the intestinal segment of 18-week-old Lushi green birds

\begin{tabular}{lcccc}
\hline \multicolumn{1}{c}{ Item } & $\begin{array}{c}\text { Semi-intensive } \\
\text { rooster }\end{array}$ & $\begin{array}{c}\text { Semi-intensive } \\
\text { hen }\end{array}$ & $\begin{array}{c}\text { Battery cage } \\
\text { rooster }\end{array}$ & $\begin{array}{c}\text { Battery cage } \\
\text { hen }\end{array}$ \\
\hline Length(cm) & & & & \\
Duodenum & $29.72^{\mathrm{a}} \pm 2.16$ & $25.02^{\mathrm{b}} \pm 1.94$ & $22.00^{\mathrm{c}} \pm 3.68$ & $22.16^{\mathrm{c}} \pm 3.22$ \\
Jejunum & $35.04^{\mathrm{a}} \pm 3.81$ & $32.54^{\mathrm{a}} \pm 4.68$ & $21.88^{\mathrm{b}} \pm 4.63$ & $22.98^{\mathrm{b}} \pm 2.61$ \\
Ileum & $40.10^{\mathrm{a}} \pm 4.28$ & $36.18^{\mathrm{a}} \pm 2.83$ & $30.62^{\mathrm{b}} \pm 2.53$ & $28.88^{\mathrm{b}} \pm 2.68$ \\
Ceca & $14.36^{\mathrm{a}} \pm 1.79$ & $13.46^{\mathrm{a}} \pm 2.63$ & $11.48^{\mathrm{b}} \pm 1.26$ & $10.74^{\mathrm{b}} \pm 0.49$ \\
Weight(g) & & & & \\
Duodenum & $11.70^{\mathrm{a}} \pm 1.06$ & $7.89^{\mathrm{b}} \pm 0.75$ & $7.43^{\mathrm{b}} \pm 1.43$ & $6.99^{\mathrm{b}} \pm 1.72$ \\
Jejunum & $14.45^{\mathrm{a}} \pm 1.97$ & $8.30^{\mathrm{b}} \pm 1.71$ & $7.67^{\mathrm{b}} \pm 1.72$ & $6.46^{\mathrm{b}} \pm 0.95$ \\
Ileum & $13.08^{\mathrm{a}} \pm 1.90$ & $7.93^{\mathrm{b}} \pm 1.25$ & $8.86^{\mathrm{b}} \pm 1.49$ & $7.43^{\mathrm{b}} \pm 1.22$ \\
Ceca & $6.61 \pm 0.61$ & $5.50 \pm 1.57$ & $4.58 \pm 0.38$ & $4.25 \pm 0.68$ \\
Intestinal weight & $45.84^{\mathrm{a}} \pm 3.89$ & $29.62^{\mathrm{b}} \pm 4.41$ & $28.53^{\mathrm{c}} \pm 4.08$ & $25.13^{\mathrm{b}} \pm 4.06$ \\
Relative length ${ }^{\mathbf{1}}(\boldsymbol{\%})$ & & & & \\
Duodenum & $28.39 \pm 0.76$ & $26.81 \pm 2.83$ & $29.53 \pm 3.10$ & $29.87 \pm 2.25$ \\
Jejunum & $33.39^{\mathrm{a}} \pm 0.85$ & $34.59^{\mathrm{a}} \pm 2.60$ & $29.20^{\mathrm{b}} \pm 3.71$ & $31.07^{\mathrm{b}} \pm 2.63$ \\
Ileum & $38.22^{\mathrm{b}} \pm 0.94$ & $38.60^{\mathrm{b}} \pm 1.29$ & $41.27^{\mathrm{a}} \pm 1.84$ & $39.06^{\mathrm{b}} \pm 2.05$ \\
\hline Val & &
\end{tabular}

Values within a row followed by different upper case letters are significantly different $(\mathrm{P}<0.05),{ }^{1}$ Calulated as a percentage of intestine length

Table 3. Effects of two rearing systems on the organ index of 18-week-old Lushi green birds

\begin{tabular}{lcccc}
\hline \multicolumn{1}{c}{ Item } & $\begin{array}{c}\text { Semi-intensive } \\
\text { rooster }\end{array}$ & $\begin{array}{c}\text { Semi-intensive } \\
\text { hen }\end{array}$ & $\begin{array}{c}\text { Battery cage } \\
\text { rooster }\end{array}$ & $\begin{array}{c}\text { Battery cage } \\
\text { hen }\end{array}$ \\
\hline Organ weight(g) & & & & \\
Liver & $27.45^{\mathrm{a}} \pm 1.55$ & $18.59^{\mathrm{b}} \pm 4.95$ & $20.79^{\mathrm{b}} \pm 1.80$ & $17.58^{\mathrm{b}} \pm 2.27$ \\
Glandular stomach & $4.99^{\mathrm{a}} \pm 0.84$ & $3.61^{\mathrm{b}} \pm 0.56$ & $4.27^{\mathrm{a}} \pm 0.63$ & $3.14^{\mathrm{b}} \pm 0.35$ \\
Gizzard & $35.36^{\mathrm{a}} \pm 2.85$ & $25.17^{\mathrm{b}} \pm 3.07$ & $22.80^{\mathrm{b}} \pm 2.97$ & $21.66^{\mathrm{b}} \pm 2.63$ \\
Pancreas & $2.91^{\mathrm{a}} \pm 0.44$ & $2.17^{\mathrm{b}} \pm 0.30$ & $2.11^{\mathrm{b}} \pm 0.44$ & $2.03^{\mathrm{b}} \pm 0.24$ \\
Organ index $\mathbf{1}(\mathbf{g} / \mathbf{K g})$ & & & & \\
Liver & $20.12^{\mathrm{ab}} \pm 0.75$ & $22.61^{\mathrm{a}} \pm 3.63$ & $17.05^{\mathrm{b}} \pm 2.70$ & $16.42^{\mathrm{b}} \pm 1.91$ \\
Glandular stomach & $3.64^{\mathrm{b}} \pm 0.40$ & $4.44^{\mathrm{a}} \pm 0.49$ & $3.48^{\mathrm{b}} \pm 0.54$ & $2.94^{\mathrm{b}} \pm 0.40$ \\
Gizzard & $25.91^{\mathrm{b}} \pm 1.54$ & $30.94^{\mathrm{a}} \pm 0.44$ & $18.61^{\mathrm{c}} \pm 2.90$ & $20.31^{\mathrm{c}} \pm 2.86$ \\
Pancreas & $2.12^{\mathrm{b}} \pm 0.22$ & $2.68^{\mathrm{a}} \pm 0.39$ & $1.73^{\mathrm{b}} \pm 0.45$ & $1.90^{\mathrm{b}} \pm 0.19$ \\
\hline
\end{tabular}

Values within a row followed by different upper case letters are significantly different $(\mathrm{P}<0.05),{ }^{1}$ Calulated as a percentage of live BW 
Table 4. Effects of two rearing systems on the carcass characteristics of 18-week-old Lushi green birds

\begin{tabular}{|c|c|c|c|c|}
\hline Item & $\begin{array}{l}\text { Semi-intensive } \\
\text { rooster }\end{array}$ & $\begin{array}{c}\text { Semi-intensive } \\
\text { hen }\end{array}$ & $\begin{array}{l}\text { Battery cage } \\
\text { rooster }\end{array}$ & $\begin{array}{c}\text { Battery cage } \\
\text { hen }\end{array}$ \\
\hline Dressed weight (g) & $1189.80^{\mathrm{a}} \pm 89.49$ & $720.80^{c} \pm 94.64$ & $1060.00^{\mathrm{a}} \pm 128.93$ & $944.00^{\mathrm{b}} \pm 125.42$ \\
\hline Eviscerated weight (g) & $847.60^{\mathrm{a}} \pm 43.80$ & $484.00^{c} \pm 50.55$ & $755.00^{\mathrm{a}} \pm 91.72$ & $668.00^{\mathrm{b}} \pm 82.36$ \\
\hline Breast muscle weight (g) & $190.08^{\mathrm{a}} \pm 14.84$ & $116.25^{\mathrm{c}} \pm 14.55$ & $164.80^{\mathrm{a}} \pm 20.62$ & $170.55^{b} \pm 30.18$ \\
\hline Thigh muscle weight (g) & $242.86^{\mathrm{a}} \pm 24.97$ & $144.53^{\mathrm{b}} \pm 14.91$ & $260.36^{\mathrm{a}} \pm 49.00$ & $223.99^{\mathrm{b}} \pm 31.29$ \\
\hline Abdominal fat weight $(\mathrm{g})$ & $1.12^{\mathrm{c}} \pm 0.19$ & $1.28^{\mathrm{c}} \pm 0.38$ & $17.98^{b} \pm 8.88$ & $24.56^{\mathrm{a}} \pm 20.94$ \\
\hline Heavy feet $(g)$ & $56.25^{\mathrm{a}} \pm 5.45$ & $27.73^{c} \pm 3.28$ & $47.48^{\mathrm{b}} \pm 5.80$ & $34.39^{c} \pm 5.42$ \\
\hline Heart weight (g) & $5.70^{\mathrm{a}} \pm 0.81$ & $3.38^{\mathrm{b}} \pm 0.51$ & $5.23^{\mathrm{a}} \pm 0.86$ & $3.74^{b} \pm 0.52$ \\
\hline Gizzard weight (g) & $35.36^{\mathrm{a}} \pm 2.85$ & $25.17^{b} \pm 3.07$ & $22.80^{c} \pm 2.97$ & $21.66^{\mathrm{b}} \pm 2.63$ \\
\hline Liver weight (g) & $27.45^{\mathrm{a}} \pm 1.55$ & $18.59^{c} \pm 4.95$ & $20.79^{\mathrm{b}} \pm 1.80$ & $17.58^{\mathrm{c}} \pm 2.27$ \\
\hline Slaughter yield ${ }^{1}(\%)$ & $87.09 \pm 1.25$ & $88.55 \pm 2.95$ & $85.87 \pm 3.46$ & $87.74 \pm 3.74$ \\
\hline Eviscerated yield ${ }^{1}(\%)$ & $62.12 \pm 1.48$ & $59.61 \pm 1.31$ & $61.15 \pm 1.84$ & $62.14 \pm 2.23$ \\
\hline Breast yield $^{2}(\%)$ & $22.41^{b} \pm 0.79$ & $23.99^{\mathrm{ab}} \pm 1.19$ & $21.83^{\mathrm{b}} \pm 0.51$ & $25.42^{\mathrm{a}} \pm 1.86$ \\
\hline Thigh muscleyield ${ }^{2}(\%)$ & $28.61^{b} \pm 1.94$ & $29.88^{\mathrm{b}} \pm 1.09$ & $34.36^{\mathrm{a}} \pm 3.43$ & $33.51^{\mathrm{a}} \pm 1.59$ \\
\hline Abdominal fat yield ${ }^{2}(\%)$ & $0.13^{\mathrm{b}} \pm 0.02$ & $0.27^{b} \pm 0.09$ & $2.32^{\mathrm{a}} \pm 1.15$ & $3.30^{\mathrm{a}} \pm 2.62$ \\
\hline
\end{tabular}

Values within a row followed by different upper case letters are significantly different $(\mathrm{P}<0.05)$

${ }^{1}$ Calulated as a percentage of live BW

${ }^{2}$ Calculated as a percentage of eviscerated carcass weight

muscle yields of the hens reared under the semi-intensive system were lower than those of the cage-reared hens $(\mathrm{P}<0.05)$; the other indexes of the hens under the two systems increased $(\mathrm{P}>0.05)$.

\section{DISCUSSION}

Effect on the development of digestive organs: The weights of the liver, glandular stomach, gizzard, pancreas and the relative weight index of the semi-intensive chickens were higher than those of the cage-reared chickens. The results indicated that the digestion and absorption functions of the chickens reared under the semi-intensive system were generally better than those of the caged chickens. This result agreed with those of Santos et al. (2008), who reported that the relative gizzard weights of broiler chickens raised on litter (soft pine shavings) are heavier than those of caged broiler chickens. Similar results were reported by Hetland and Svihus (2001) who fed broiler chickens with diets containing oat hulls. Gonzálezalvarado et al. (2008) found that a minimal amount of fiber in broiler chicken diet is required to stimulate the development of the gastrointestinal tract. In the present experiment, the birds raised in the semi-intensive system gained access 
to pasture and various forages, insects and worms; consequently, their crude fiber content was higher than that of the caged chickens. In the low digestion and absorption of physiological conditions, the body can show compensatory physiological reaction, which increases creep dynamic strength and digestive organ weight, promotes the proliferation of digestive organs, and increases the secretion of digestive enzymes. This result can be attributed to the high-quality food utilized. In addition, the digestive organs of the roosters were heavier than those of the hens, which caused the slightly lower organ index of the roosters compared with the hens.

Animal internal organs adapt to the external environment; the internal organ weight and relative weight index can be used as approximate indicators to measure function (Ciftci et al., 2003; Lalpanmawia et al., 2014). The results of the present study indicated that the length and weight of the intestinal segments of the semi-intensive chickens were higher than those of the cagereared chickens. Contrarily, Santos et al. (2008) reported that the relative total intestine weight and length of broiler chickens reared on litter are lighter and shorter than those of chickens reared in cages. Such contrasting results on intestine weight might be due to the different environmental conditions, physiologies or breeds.

Effect on the slaughter performance: The breast muscle, thigh muscle and carcass yields are indicators reflecting the carcass quality of poultry (Dransfield and Sosnicki, 1999; Castellini et al., 2002). Lushi green layer birds showed a high slaughter rate
(Table 4) under different raising methods. The abdominal fat yield of the semiintensive in Lushi green layer birds was less than that of the cage-reared chickens. The reduced abdominal fat may have resulted from the considerable motion and muscle mass development, which is in accordance with the result of Ricard (1977); Lewis et al. (1997) and Castellini et al. (2002).

In the present study, no significant differences existed in carcass yields. However, the thigh muscle yield of the semi-intensive chickens was less than that of the caged ones. On the contrary, Ricard (1977) and Castellini et al. (2002) found that the percentages of breast and thigh meat increase when birds gain an outdoor access; furthermore, the stocking density in an organic production system is low because of forced motor activity. Such contrasting results on thigh muscle yield might be due to the different rearing patterns. Jiang et al. (2008) found that the half eviscerated and eviscerated yields of semi-intensive chickens are higher than those of all caged chickens. Moreover, the slaughter, leg muscle and gizzard yields of the caged chickens are better than those of semiintensive ones. Comparison of the free and caged chickens shows that the abdominal fat yield is reduced by $12.2 \%$. The present results are not completely consistent with this observation, which is probably due to the different chicken breeds used.

Semi-intensive system had a limited effect on slaughter performance and digestive organ development of Lushi green layer birds. The digestion and absorption abilities 
of the chickens reared under the semiintensive system were better than those of the caged ones. The results of this study imply that semi-intensive system, in which birds can roam around during daytime to scavenge, might be a feasible and effective system for Lushi green layer birds.

Conflict of interest: Authors declare that there is no conflict of interest regarding the present research work.

\section{REFERENCES}

Barbosafilho JA, Silva MA, Coelho AA and Savino VJ, 2005. Behavior and performance of broiler strains reared under semi-intensive system with shaded areas. Braz J Poult Sci, 7(4): 209-213

Baxter MR, 1994. The welfare problems of laying hens in battery cages. Vet Rec,134(24): 614619

Castellini C, Mugnai C and Dal BA, 2002. Effect of organic production system on broiler carcass and meat quality. Meat Sci, 60(3): 219-225

Ciftci I, Yenice E and Eleroglu H, 2003. Use of triticale alone and in combination with wheat or maize: effects of diet type and enzyme supplementation on hen performance, egg quality, organ weights, intestinal viscosity and digestive system characteristics. Anim Feed Sci Tech, 105(1): 149-161

Dereuk K, Messens W, Herman L, Hendricks M and Rodenburg T et al., 2008. Bacterial contamination of table eggs and influence of housing systems. World Poult Sci J, 64(1):5-19

Dransfield E and Sosnicki AA, 1999. Relationship between muscle growth and poultry meat quality. Poult Sci, 78(5): 743-746

Fanatico AC, Cavitt LC, Pillai PB, Emmert JL and Owens CM, 2005. Evaluation of slowergrowing broiler genotypes grown with and

\section{ACKNOWLEDGEMENTS}

This study was supported by the Key Science and Technology Project of Henan (Research and application of molecular breeding techniques of Lushi chicken, 82102130001) and the Key Science and Technology Project of Luoyang (Research and demonstration of ecological farming model of Lushi chicken, 0701040A).

without outdoor access: meat quality. Poult Sci, 84(11): 1321-1327

Gonzálezalvarado JM, Jiménezmoreno E, Valencia DG, Lázaro R and Mateos GG, 2008. Effects of fiber source and heat processing of the cereal on the development and $\mathrm{Ph}$ of the gastrointestinal tract of broilers fed diets based on corn or rice. Poult Sci, 87(9): 1779

Hameed T, Bajwa MA, Abbas F, Sahota AW and Tariq MM et al., 2012. Effect of housing system on production performances of different broiler breeder strains. Pak J Zool, 44(6): 1683-1687

Hetland H and Svihus B, 2001. Effect of oat hulls on performance, gut capacity and feed passage time in broiler chickens. Brit Poult Sci, 42(3): 354

Huang YK, Yang PK, Ji XB, Du Y and Ma WJ et al., 2017. Current situation of Lushi chicken and countermeasures for breed conservation and exploration. Guizhou Agricultural Sci, 5(2): 117-119

Jiang N, Meng H, Zhigang LI, Gao H and Yuan AN et al., 2008. Effects of rotational grazing on carcass traits and meat quality in quality chicken. China Poult, 30(8): 34-36

Jones RB and Mills AD, 1999. Divergent selection for social reinstatement behaviour in japanese 
quail: effects on sociality and social discrimination. Avian Poult Bio Rev, 10(4): 213-223

Kilpinen O, Roepstorff A, Permin A, Norgaard NG and Lawson LG et al., 2005. Influence of Dermanyssus gallinae and Ascaridia galli infections on behaviour and health of laying hens (Gallus gallus domesticus). Brit Poult Sci J, 46(1): 26-34

Lalpanmawia H, Elangovan AV, Sridhar M, Shet D and Ajith S et al., 2014. Efficacy of phytase on growth performance, nutrient utilization and bone mineralization in broiler chicken. Anim Feed Sci Tech, 192(6): 81-89

Lewis PD, Perry GC, Farmer LJ and Patterson RL, 1997. Responses of two genotypes of chicken to the diets and stocking densities typical of UK and 'Label Rouge' production systems: I. Performance, behaviour and carcass composition. Meat Sci, 45(4): 501-516

Ma XH, Kang XT, Sun GR, Tian YD and Pan J et $a l ., 2009$. Effects of different feeding manners on the meat quality of Lushi chicken. Acta Ecologiae Anim Domastici, 30(5): 52-55

Marin RH, Freytes P, Guzman D and Bryan JR, 2001. Effects of an acute stressor on fear and on the social reinstatement responses of domestic chicks to cagemates and strangers. Appl Anim Behav Sci, 71(1): 57

Mendl M, 1999. Performing under pressure: stress and cognitive function. Appl Anim Behav Sci, 65(3): 221-244

Muchadeyi FC, Sibanda S, Kusina NT, Kusina J and Makuza S, 2004. The village production system in Rushinga district of Zimbabwe. Livestock research for rural development. Available in http//www.Irrd.org/Irrd16/6/ much 16040.pdf. [15 Mar, 2013]

Niranjan M, Sharma R, Rajkumar U, Reddy B and Chatterjee $\mathrm{R}$ et al., 2008. Comparative evaluation of production performance in improved chicken varieties for backyard farming. Inter J Poult Sci, 7(11): 1128 -1131

Njoya J and Picard M, 1994. Climatic adaptation of laying hens. Trop Anim Health Pro, 26(3): 180-186

Ricard T, 1977. Influence de l'age et du patrimone génétique sur l'état d'engraissement du poulet in La composition corporelle des volailles. INRA, Paris, France, pp 79-86

Rodenburg TB, Frank AM and Bart B, 2005. Welfare, health, and hygiene of laying hens housed in furnished cages and in alternative housing systems. J Appl Anim Welf Sci, 8(3): 211-226

Santos FB, Sheldon BW, Jr SA and Ferket PR, 2008. Influence of housing system, grain type, and particle size on salmonella colonization and shedding of broilers fed triticale or cornsoybean meal diets. Poult Sci, 87(3): 405-420

Thiele $\mathrm{H}$ and Pottguter R, 2008. Management recommendations for laying hens in deep litter, perchery and free range systems. Lohmann Information, 43: 53

Vits A, Weitzenbürger D and Distl O, 2005. Comparison of different housing systems for laying hens in respect of economic, health and welfare aspects with special regard to furnished cages (review article). Dtsch Tierarztl Wochenschr, 112(9): 332-342

National RC, 1994. Nutrition requirement of poultry. National Academy Press. Washington DC

Xu TS, Lei XQ, Zhang D, Wu QJ and Xiao ZQ et al., 2009. Effect of rearing ways on carcass performance of Lushi green-shell-egg chickens. China Anim Husb Vet Med, 36(12): 178-180

Zhou Y, Fu SY, Ren TH, Song YY and Jiang RR et al., 2016. Analysis on color change rule of green-shell eggs in different weeks of age of Lushi chickens. China Poult, 38(19): 15-18 